\title{
Zinc Serum Maternal Levels as a Risk Factor for Preeclampsia
}

\author{
Abarham Martadiansyah ${ }^{1 *}$, Peby Maulina ${ }^{1}$, Putri Mirani $^{1}$, Tia Kaprianti $^{1}$, Theodorus $^{2}$
}

${ }^{1}$ Department of Obstetric and Gynecology, Faculty of Medicine, Universitas Sriwijaya, Palembang, Indonesia

2Department of Obstetric and Gynecology, Dr Moh Hoesin General Hospital, Palembang, Indonesia

\author{
A R T I C L E I N F O \\ Keywords: \\ Preeclampsia \\ Zinc \\ Case Control Study \\ *Corresponding author: \\ Abarham Martadiansyah \\ E-mail address: \\ drabarhammartadiansyah@gmail.com
}

All authors have reviewed and approved the final version of the manuscript.

\section{https://doi.org/10.32539/bsm.v5i7.390}

\begin{abstract}
A B S T R A C T
Background: Preeclampsia is defined as gestational hypertension and proteinuria which can be measured by the elevation of liver transaminases to twice normal concentration, and the symptoms of increased intracranial pressure such as dizziness, blurred vision, and seizures. Zinc is an essential mineral for many biological functions and one of the trace elements that is directly involved in the oxidative/antioxidant balance, a pathogenesis process in preeclampsia that is highly dependent on dietary habits and supplements. This study was aimed to assess the association between serum zinc level with preeclampsia (PE). Methods: This observational, case-control study was performed on 90 women with singleton pregnancies at 28 to 42 weeks of gestation which were referred to the Department of Obstetrics and Gynecology, Dr. Mohammad Hoesin General Hospital, Palembang, between August 2020 to November 2020. 30 pregnant women with PE were selected as cases and 60 healthy pregnant women were selected as controls. Maternal serum zinc samples were collected. The collected data were entered into the master table. Tabulation, coding, and statistical data analysis were performed using SPSS version 20.0 for Windows. Results: The mean serum zinc levels in the case group and control group were $43,90 \pm 15,79 \mu \mathrm{g} / \mathrm{dL}$ (ranged from 15 to $86 \mu \mathrm{g} / \mathrm{dL}$ ) and 48,77 $\pm 10,54$ $\mu \mathrm{g} / \mathrm{dL}$ (ranged from 22 to $83 \mu \mathrm{g} / \mathrm{dL}$ ), respectively. A value of serum zinc levels with the best sensitivity and specificity was $45,5 \mu \mathrm{g} / \mathrm{dL}$. Conclusion: There was a significant association between maternal serum zinc level with $\mathrm{PE}$. The risk of $\mathrm{PE}$ was 3,2 times higher in pregnant women with serum zinc levels of $\leq 45,5 \mathrm{mcg} / \mathrm{dL}$ compared to pregnant women with serum zinc levels of $>45,5 \mathrm{mcg} / \mathrm{dL}$. In this case it is necessary to supplement zinc earlier in pregnancy to reduce the risk of preeclampsia.
\end{abstract}

\section{Introduction}

Preeclampsia (PE) is defined as gestational hypertension and proteinuria $\geq 300 \mathrm{mg} / 24$ hours or protein/creatinine ratio $\geq 0.3$ or a $(+)$ value in the urine dipstick test, or the presence of thrombocytopenia with platelets $<100,000 / \mu \mathrm{L}$, renal insufficiency (creatinine $>$ $1.1 \mathrm{mg} / \mathrm{dL}$ ), impaired liver function which can be measured by the elevation of liver transaminases to twice normal concentration, and the symptoms of increased intracranial pressure such as dizziness, blurred vision, and seizures. ${ }^{1}$ The incidence of $\mathrm{PE}$ varies worldwide. Based on the secondary analysis of the World Health Association (WHO) Global Survey on Maternal and Perinatal Health in 24 countries in the world, the prevalence of preeclampsia is 10,754 of 276,388 mothers (4\%). PE and eclampsia are significant risk factors for maternal mortality, perinatal mortality, preterm birth, and low birth weight. Nearly 1 in 10 maternal deaths in Asia and Africa are associated with gestational hypertension, and $\mathrm{PE}$ and eclampsia have the greatest impacts on the maternal and 
neonatal morbidity and mortality. ${ }^{2-3}$ Oxidative stress is one of the etiopathogenesis of PE. ${ }^{1}$

Zinc is an essential mineral for many biological functions including protein synthesis, cell division, and nucleic acid metabolism, and one of the trace elements that is directly involved in the oxidative/antioxidant balance, a pathogenesis process in $\mathrm{PE}$ that is highly dependent on dietary habits and supplements. Several studies have found significantly lower serum zinc levels in $\mathrm{PE}$ patients compared to non-PE pregnancies. Kamru et al. demonstrated that serum zinc levels were $43 \%$ lower in women with PE when compared to normal pregnant women in Turkey. A study in India compared serum zinc levels between women with PE and controls. Serum zinc levels in women with mild PE and severe PE were lower, which were $12.72 \mu \mathrm{mol} / \mathrm{L}$ in mild PE and $12.04 \mu \mathrm{mol} / \mathrm{L}$ in severe PE, compared to $15.64 \mu \mathrm{mol} / \mathrm{L}$ in women with normal pregnancy. ${ }^{4-7}$

Scarce studies have been conducted on the benefits of zinc in PE in Indonesia, especially in Palembang. We aimed to assess the association between zinc and PE in pregnant women which were referred to Dr. Mohammad Hoesin General Hospital, Palembang.

\section{Methods}

This observational, case-control study was conducted in the Department of Obstetrics and Gynecology, Dr. Mohammad Hoesin General Hospital, Palembang, in August 2020 to October 2020. Our study population were all pregnant women with singleton pregnancies at 28 to 42 weeks of gestation which were referred to the Department of Obstetrics and Gynecology, Dr. Mohammad Hoesin General Hospital, Palembang. Protocol study has been approved by ethical committee Dr. Mohammad Hoesin General Hospital, Palembang.

The inclusion criteria in the case group included diagnosis of $\mathrm{PE}$, singleton pregnancy, at 28 to 42 weeks of gestation. For the control group, the inclusion criteria included singleton pregnancy at 28 to 42 weeks of gestation. Controls received the same treatment as other normal pregnancies. Both groups willed to participate in the study and signed an informed consent form. The exclusion criteria for both groups were a gestational age of less than 20 weeks, multiple pregnancy, pregnancy with complications, such as antepartum hemorrhage, liver disease, kidney disease, heart disease, diabetes mellitus, and metabolic disorders, fetal death, intrauterine growth restriction, and patients who refused to participate in the study.

Samples were selected by consecutive sampling according to the day the patient was diagnosed with PE (time of diagnosis). Anamnesis, physical examination (vital signs, head to toe), gynecological examination (external examination and internal examination, or as indicated), additional examinations (ultrasound and laboratory) were performed according to the guidelines of the Department of Obstetrics and Gynecology, Dr. Mohammad Hoesin General Hospital, Palembang. Samples who agreed to participate in the study were randomly classified into controls (non-preeclamptic women) and cases (preeclamptic women). Maternal serum zinc samples were collected and measured in the Prodia Palembang Laboratory. Tools and materials needed during the research were stationary (ball point), tourniquet, stetoscope, weight scale, roll meter, Aglient 7700. Disposables included 3cc syringes, trace element blood sample tubes, alcohol swabs, and Randox kits.

All data were collected and tabulated into data tables, matching was carried out based on age, body mass index (BMI), education level, marital status, obstetric status, socioeconomic level, address, occupation, and maternal disease. Matching was also performed on demographic variable data (bias variables). The collected data were entered into the master table. Tabulation, coding, and statistical data analysis were performed using SPSS version 20.0 for Windows. Data analysis were performed according to the type of data and the type of data distribution (Kolgomorov-Smirnov test). Chi Square/Fisher's test was conducted on nominal and categorical data. T-test or Mann-Whitney $U$ test was conducted on interval data. The results were presented in tables and figures with a confidence interval (CI) of 95\%. Success parameter of this study was an association between serum zinc levels and $\mathrm{PE}$ with an odds ratio of $>2(\mathrm{p}$ $<0.05)$. 


\section{Result}

A total of 90 pregnant women fulfilled the inclusion criteria. There were 60 cases and 30 controls. The mean age of the case group was $31.23 \pm 5.83$ years (ranged between 20 to 41 years) with majority of the samples were $>30$ years $(53.3 \%)$, meanwhile, the mean age of the control group was 29,25 \pm 6.77 years (ranged between 17 to 44 years) with majority of the samples were $>30$ years (48.3\%). Although the mean age of the control group was slightly younger, this difference was not statistically significant $(\mathrm{p}=0.138)$. There was no difference in age categories $(p=0.266)$ between cases and controls.

Majority of cases and controls have higher education level (high school) (90\% and 83.3\%, respectively) and most of them were housewives $(80 \%$ and $85 \%$, respectively). There was no statistical difference in education level $(p=0.342)$ and occupation $(\mathrm{p}=0.319)$ between cases and controls.

There was no difference in BMI between the normoweight and overweight groups $(\mathrm{p}=0.246)$ between cases and controls. $73.3 \%$ of the cases were overweight.

Most pregnant women in the case group were at 37 to 42 weeks $(75.9 \%)$ and majority were multiparous (43.3\%). Similar results shown in the control group, they were at 37 to 42 weeks pregnant (63.3\%) and majority were also multiparous (43.3\%). There was no difference in gestational age $(\mathrm{p}=0.347)$ and parity $(\mathrm{p}=$ 0.940) between cases and controls. The data can be seen in Table 1.

Table 1. Characteristics of subjects in the case and control group ( $\mathrm{n}=90)$

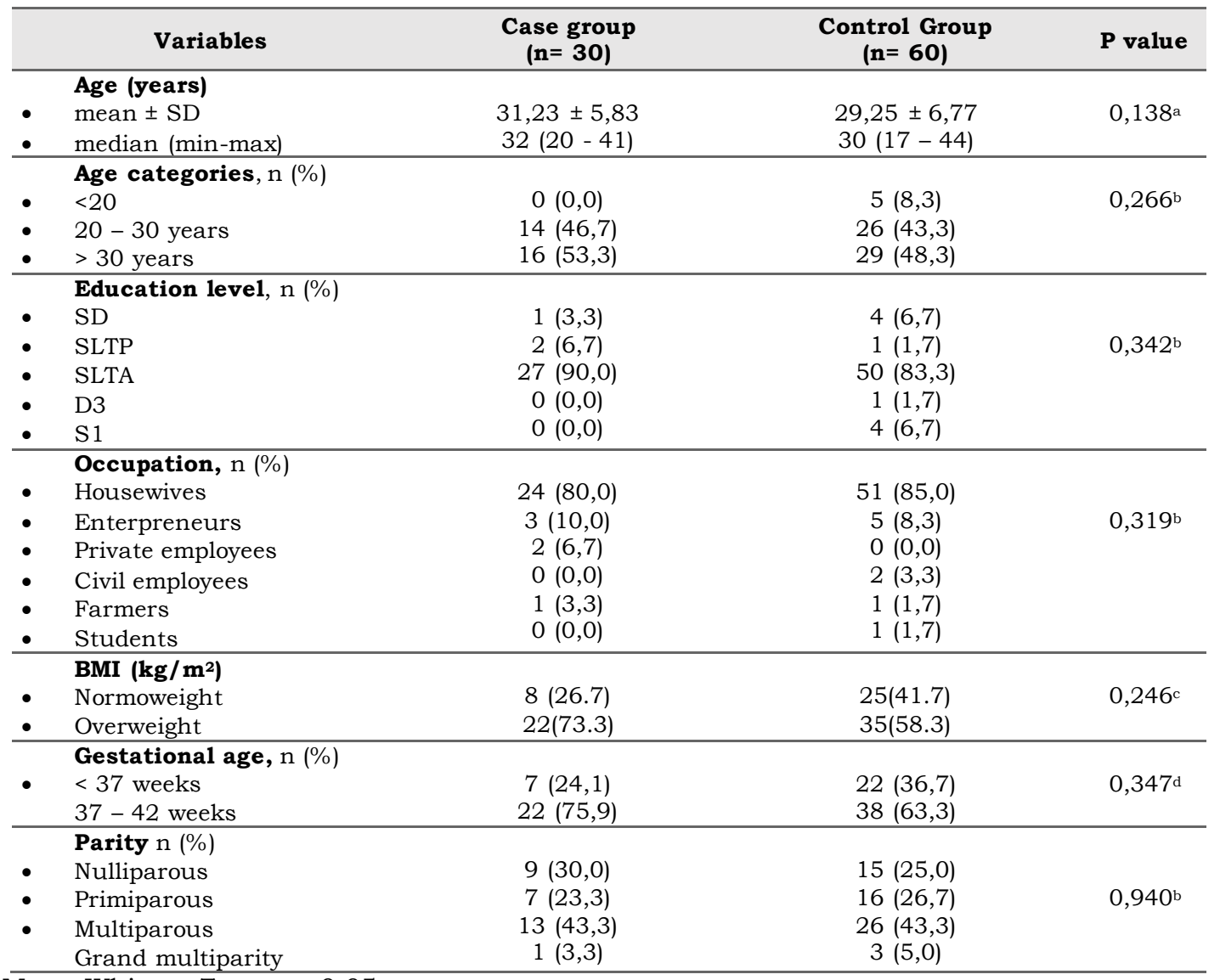

a Mann Whitney Test, $\mathrm{p}=0,05$

bPearson Chi Square Test, $\mathrm{p}=0,05$

continuity correction, $\mathrm{p}=0,05$

dChi Square Test, $\mathrm{p}=0,05$ 
The mean serum zinc levels in the case group and control group were 43,90 $\pm 15,79 \mu \mathrm{g} / \mathrm{dL}$ (ranged from 15 to $86 \mu \mathrm{g} / \mathrm{dL}$ ) and $48,77 \pm 10,54 \mu \mathrm{g} / \mathrm{dL}$ (ranged from 22 to $83 \mu \mathrm{g} / \mathrm{dL})$, respectively. There was a significant difference in serum zinc levels between cases and controls $(\mathrm{p}=0.013)$. The serum zinc levels of pregnant women with PE were lower than not PE. (Table 2).

Table 2. Serum zinc levels $(n=90)$

\begin{tabular}{lccc}
\hline \multicolumn{1}{c}{ Variables } & $\begin{array}{c}\text { Cases } \\
(\mathbf{n = 3 0 )}\end{array}$ & $\begin{array}{c}\text { Controls } \\
(\mathbf{n = 6 0 )}\end{array}$ & $\begin{array}{c}\text { P } \\
\text { value }\end{array}$ \\
\hline Serum zinc levels & & & \\
- Mean SD & $43,90 \pm 15,79$ & $48,77 \pm 10,54$ & 0,013 \\
- Median (min-max) & $41(15-86)$ & $49,5(22-83)$ & \\
\hline
\end{tabular}

To find the cut-off point of serum zinc levels, analysis was carried out using a receiver operating curve (ROC) by making a curve between the sensitivity, specificity and serum zinc levels of pregnant women
(Figure 1). Based on the cut-off curve of serum zinc levels, a value of serum zinc levels with the best sensitivity and specificity was $45,5 \mu \mathrm{g} / \mathrm{dL}$. (Figure 2 ).

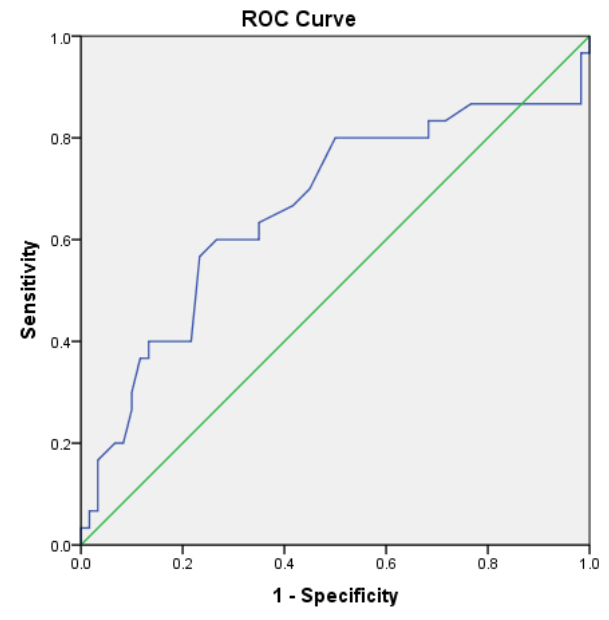

Diagonal segments are produced by ties.

Figure 1. ROC of serum zinc levels

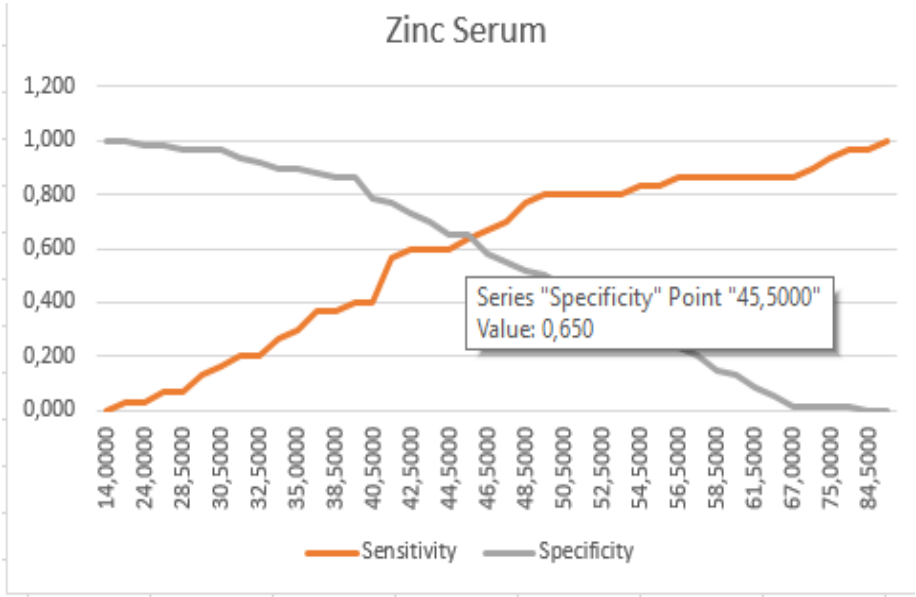

Figure 2. Cut-off curve of sensitivity, specificity, and serum zinc levels 
Serum zinc levels $\leq 45.5 \mu \mathrm{g} / \mathrm{dL}$ were found in 19 out of 30 cases (63.3\%) and 21 out of 60 controls (35\%). There was a significant relationship between serum zinc levels and the incidence of PE. Pregnant women with serum zinc levels $\leq 45.5 \mu \mathrm{g} / \mathrm{dL}$ are 3.2 times more likely to experience $\mathrm{PE}$ compared to pregnant women with serum zinc levels > 45.5 $\mu \mathrm{g} / \mathrm{dL}(\mathrm{OR}=3.208$ (CI95\% 1.288 - 7.990); $\mathrm{p}=0.020$ ) (Table 3).

Table 3. The association between zinc serum level and PE

\begin{tabular}{cccccc}
\hline & \multicolumn{2}{c}{ PE } & & \\
Characteristic & Yes & No & Total & $\begin{array}{c}\text { OR } \\
\text { (IK95\%) }\end{array}$ & $\begin{array}{c}\text { P } \\
\text { value }\end{array}$ \\
& & & & & \\
\hline $\begin{array}{c}\text { Zinc Serum zinc levels } \\
\bullet \quad \leq 45,5 \mu \mathrm{g} / \mathrm{dL}\end{array}$ & $\mathbf{1 9}$ & $\mathbf{2 1}$ & 40 & 3,208 & 0,020 \\
$\bullet \quad \mathbf{1 1}$ & $\mathbf{3 9}$ & 50 & $(1,288-7,990)$ & \\
\hline Total & 30 & 60 & 90 & & \\
\hline
\end{tabular}

\section{Discussion}

Hypertension in pregnancy is used to describe blood pressure disorders in patients who may only have mild elevated blood pressure or severe hypertension with several organ dysfunction including chronic hypertension, gestational hypertension, superimposed $\mathrm{PE}, \mathrm{PE}$, eclampsia, and hemolysis syndrome in the form of elevated liver enzymes and decreased platelet count (HELLP syndrome). 8 The criteria for severe preeclampsia are the presence of one or more symptoms of systolic blood pressure greater than 160 $\mathrm{mmHg}$ and diastolic blood pressure equal to or more than $110 \mathrm{mmHg}$, proteinuria more than $2 \mathrm{~g} / 24$ hours or +2 , qualitatively. 9

Age has an important influence on the incidence of hypertension in pregnancy. A pregnant woman who is 35 years or older is defined as "advanced maternal age (AMA)". 10 Research conducted by Morikaw et al. in 2013 reported that the relationship between maternal age and $\mathrm{PE}$ forming a U-shaped curve. the lowest frequency was in women aged 25-29 years, while the high frequency was found in women aged less than 20 years and more than 35 years. 11

This study showed the mean age of cases was 31.23 \pm 5.83 years, ranged between 20 to 41 years and majority of them were $>30$ years old $(53.3 \%)$. This result is not different from the study conducted by Siddiqui et al., in 2020 which reported that 95 pregnant women with PE had a mean age of $31.3 \pm 5.1$ years. ${ }^{12}$ Curiel-Balsera et al. also reported that the mean age of 203 severe PE patients was $31 \pm 5.0$ years. In 2017, Bokslag et al. reported that the mean age of $131 \mathrm{PE}$ patients was $30.9 \pm 5.0$ years. 13,14

The incidence of PE increased by 3.97 times in extremely obese people and 3.25 times in obese people with a BMI of $27.5-30.0 \mathrm{~kg} / \mathrm{m}^{2}$, and 1,60 times in people with a BMI of $25.0-27.5 \mathrm{~kg} / \mathrm{m}^{2} .15$ The result found that most of the cases were overweight $(73.3 \%)$. This result is not much different from a study conducted by Yu $Z$ et al. in 2019. The mean BMI of 80 $\mathrm{PE}$ patients from two treatment groups in their study was $28.0 \pm 5, \mathrm{~kg} / \mathrm{m}^{2}$ and $27.0 \pm 6.0 \mathrm{~kg} / \mathrm{m}^{2} .11$ A metaanalysis study of 92 studies involving 25,356,688 pregnant women conducted by Bartsch et al., in 2016 reported that pregnant women with a BMI before pregnancy $>30$ were 2.8 times more likely to suffer from $\mathrm{PE}(\mathrm{RR}=2.8 ; 95 \% \mathrm{CI} 2,6-3,1) .16$

$\mathrm{PE}$ is often experienced by young women and nulliparous. The incidence of PE in multiparous women also varies but is lower than nulliparous, nulliparous women are 1.8 times more likely to suffer from PE than primiparous $(\mathrm{RR}=1.78 ; \mathrm{p}=0.000) .15$ Research conducted by Morikawa et al., in 2013 reported that PE occurred in $2.7 \%$ nulliparous women and $1.9 \%$ multiparous women. ${ }^{11}$ However, we found that the majority of PE patients were multiparous (43.3\%). This 
result is accordance with the results of research conducted by Winarko and Yusuf in 2020 which reported that the majority of $\mathrm{PE}$ patients were multiparous (61.54\%) and research conducted by Siddiqui et al. which also reported that the majority of $\mathrm{PE}$ patients were multiparous (57.1\%). ${ }^{12}$

In addition, there were no significant differences in age, age categories, BMI, education level, occupation, or parity in cases and controls. It means that these variables did not affect the incidence of $\mathrm{PE}$ so it was reasonable for both groups to be compared.

Adequate maternal nutrition before and during pregnancy is very important for the health of both mother and child. Poor nutrition in pregnancy can interfere with the health of both mother and baby. Each year, 3.5 million deaths in women and children are attributed to malnutrition. ${ }^{17}$ Zinc acts as an intracellular signaling molecule capable of communicating between cells by converting extracellular stimuli to intracellular signals and controlling intracellular action. Changes in zinc homeostasis and dysfunction in the signaling function of zinc can lead to the pathogenesis of several diseases. Several studies have shown that lower plasma zinc levels are associated with impaired pregnancy outcomes such as fetal malformations, intrauterine growth restriction, preterm birth, $\mathrm{PE}$, and postpartum hemorrhage. 18

$\mathrm{PE}$ is caused by several factors and several studies have shown that $\mathrm{PE}$ is associated with an imbalance of increased lipid peroxides (LPO) and decreased antioxidants. Zinc also acts as an antioxidant so that zinc deficiency can cause increased lipid peroxidation. Several studies have found significantly lower serum zinc levels in $\mathrm{PE}$ patients compared to non-PE pregnancies. 5

A study by Akhtar et al. in 2011 reported that there was a significant difference in zinc levels between pregnant women with $\mathrm{PE}$ and normal pregnancies (902.50 $\pm 157.15 \mu \mathrm{gm} / \mathrm{L}$ versus $1153.33 \pm 67.09$ $\mu \mathrm{gm} / \mathrm{L} ; \mathrm{p}<0.000) .{ }^{19}$ Another study conducted by Farzin et al. in 2012 showed that there was a significant difference in zinc levels between pregnant women with $\mathrm{PE}$ and controls $(76.49 \pm 17.62 \mu \mathrm{g} / \mathrm{dL}$ versus $100.61 \pm$
$20.12 \mu \mathrm{g} / \mathrm{dL} ; \mathrm{p}<0.001)$. In 2010, Akinloye et al. reported a significant difference in zinc levels between pregnant women with $\mathrm{PE}$ and controls (8.6 \pm 1.4 $\mu \mathrm{mol} / \mathrm{L}$ versus $9.4 \pm 0.8 \mu \mathrm{mol} / \mathrm{L} ; \mathrm{p}<0.05) .{ }^{8}$ A study conducted by Sarwar et al. in 2013 also reported a significant difference in zinc levels between pregnant women with $\mathrm{PE}$ and controls $(0.77 \pm 0.05 \mathrm{mg} / \mathrm{dL}$ versus $0.98 \pm 0.03 \mathrm{mg} / \mathrm{dL} ; \mathrm{p}=0.000) .21$

Furthermore, it was found that zinc levels were lower compared to other studies. The difference in the results of the study was probably due to the subjects' gestational age. We concluded pregnant women at 28 to 42 weeks while it could be earlier in other studies, such as at 20 weeks of gestation.

Zinc has its own uniqueness because it has functions in regulatory, catalytic, and structural cells in various biological systems. Zinc plays a role in carbohydrate, lipid, protein metabolism as well as nucleic acid synthesis and degradation through its role in the carbonic anhydrase enzymes (CO2 and $\mathrm{HCO} 3$ metabolism), thimidine kinase/DNA and RNA polymerase (nucleic acid and protein synthesis). Zinc is essential for a variety of functions including growth and development, reproductive function, sensory and immune functions, antioxidants, and membrane stabilization. 22,23

One of the important functions of zinc is its role in the structure and function of the biomembrane. Several researchers have shown that decreased concentration of zinc in the biomembrane underlies several disorders associated with zinc deficiency. Zinc is an important component of several enzymes that regulate cell growth, protein and DNA synthesis, energy metabolism, regulation of gene transcription, hormone levels, and growth factor metabolism.24,25 In the preconception period, zinc supplementation is used to increase fertility and healthy childbirth. Poor maternal zinc status is associated with fetal malformations, intrauterine growth restriction, preterm delivery, $\mathrm{PE}$, and postpartum hemorrhage. 26

Placental oxidative stress is considered to be related to the pathogenesis of PE. There is a lot of evidence to suggest the contribution of oxidative stress to endothelial dysfunction which leads to PE. In humans, 
there are three forms of superoxide dismutases (SOD): cytosolic $\mathrm{Cu} / \mathrm{Zn}$-SOD, mitochondrial Mn SOD, and extracellular SOD. SODs are metalloenzymes that catalyze the dismutation of superoxide anions into oxygen and hydrogen peroxide molecules and thus form an important part of the cellular antioxidant defense mechanism. 27

There are increased concentrations of markers of oxidative stress and decreased concentrations of antioxidants in circulating maternal and placental in women with $\mathrm{PE}$. The increase in lipid peroxidation biomarkers (MDA) was accompanied by reduced SOD and GPx in pre-eclamptic cord blood and eclamptic pregnancies compared to normal pregnancies. The antioxidant enzyme SOD has been shown to be reduced in patients with PE and eclampsia in the same study. Certain substrates and co-factors are required for adequate antioxidant enzyme function. Glutathione is a substrate for enzymes that catalyze the reduction of reactive oxygen species and free radicals. 27

Zinc is one of the regulators of angiogenesis because it is related to cell proliferation, differentiation and apoptosis.28 Zinc is also a major biomembrane component and is very important for the structure and function of a membrane. Zinc modulates signal transduction in endothelial cells that affects angiogenesis. ${ }^{29} \mathrm{~A}$ study proved the association between zinc and endothelial dysfunction. Zinc has a membranestabilizing effect that helps control cell damage due to apoptosis. Several studies have found significantly lower serum zinc levels in PE patients compared to nonPE pregnancies. ${ }^{5}$

\section{Conclusion}

There was a significant difference in serum zinc levels between cases and controls $(p=0.013)$. The serum zinc levels of pregnant women with PE were lower than those of non-PE pregnant women. Based on the cut-off curve for serum zinc levels, a value of serum zinc levels with the best sensitivity and specificity was $45,5 \mu \mathrm{g} / \mathrm{dL}$. There is a significant association between serum zinc levels and the incidence of PE. Pregnant women with serum zinc levels $\leq 45.5 \mu \mathrm{g} / \mathrm{dL}$ are 3.2 times more likely to experience $\mathrm{PE}$ compared to pregnant women with serum zinc levels $>45.5 \mu \mathrm{g} / \mathrm{dL}$ $(\mathrm{OR}=3.208$ (CI95\% 1.288 - 7.990); $\mathrm{p}=0.020)$. Maternal zinc levels can be used as a predictor of preeclampsia because the ideal cut-off point has been obtained and it can help to diagnose PE. There were no significant differences in the mean age, age categories, and gestational age. Further studies should be carried out to investigate if the risk of developing PE can be decreased by providing zinc supplementation early in pregnancy.

\section{References}

1. Cunningham FG, Leveno KJ, Bloom SL, Spong CY, Dashe JS, Hoffman BL, et al. Hypertensive disorders. In: Williams Obstetric. 24th ed. New York: McGraw-Hill; 2014. p.729-31.

2. Bilano VL, Ota E, Ganchimeg T, Mori R, Souza JP. Risk factors of pre-eclampsia/eclampsia and its adverse outcomes in low- and middleincome countries: A WHO secondary analysis. PLoS ONE. 2014;9(3): e91198.

3. World Health Organization [Internet]. WHO recommendations for prevention and treatment of preeclampsia and eclampsia implications and actions [cited 2021 January 28]. Available from https:/ / apps.who.int/iris/bitstream/handle/ 10665/119627/WHO_RHR_14.17_eng.pdf?se quence $=1$.

4. Atamer $\mathrm{Y}$, Kocyigit $\mathrm{Y}$, Yokus B, Atamer A, Erden AC. Lipid peroxidation, antioxidant defense, status of trace metals and leptin level in preeclampsia. Eur J Obstet Gynecol Repro Biol. 2005; 119:61-5.

5. Ma Y, Shen X, Zhang D. The relationship between serum zinc level and preeclampsia: A meta-analysis. Nutrients. 2015; 7:7806-20.

6. Kumru S, Aydin, S, Simsek M, Sahin K, Yaman M, Ay G. Comparison of serum copper, zinc, calcium, and magnesium levels in preeclamptic and healthy pregnant women. Biol Trace Elem Res. 2003; 94:105-112.

7. Jain S, Sharma P, Kulshreshtha S, Mohan G, Singh S. The role of calcium, magnesium, and 
zinc in pre-eclampsia. Biol Trace Elem Res. 2010;133:162-170.

8. Akinloye O, Oyewale OJ, Oguntibeju OO. Evaluation of trace elements in pregnant women with pre-eclampsia. African $\mathrm{J}$ Biotechnol. 2010;9(32):5196-202.

9. American College of Obstetricians and Gynecologists. Gestational hypertension and preeclampsia. ACOG Practice Bulletin No. 222. Obstet Gynecol. 2020;135:e238.

10. Bayrampour H, Heaman M. Advanced maternal age and the risk of cesarean birth: A systematic review. Birth. 2010;37(3):219-26.

11. Morikawa M, Yamada T, Yamada T, Sato S, Cho K, Minakami H. Effects of nulliparity, maternal age, and pre-pregnancy body mass index on the development of gestational hypertension and preeclampsia. Hypertens Res Pregnancy. 2013;1(2):75-80.

12. Siddiqui A, Deneux-Tharaux C, Luton D, Schmitz T, Mandelbrot L, Estellat C, et al. Maternal obesity and severe pre-eclampsia among immigrant women: a mediation analysis. Sci Rep. 2020;10(1):1-10.

13. Curiel-Balsera E, Prieto-Palomino MÁ, MuñozBono J, Ruiz de Elvira MJ, Galeas JL, Quesada García G. Analysis of maternal morbidity and mortality among patients admitted to Obstetric Intensive Care with severe preeclampsia, eclampsia or HELLP syndrome. Med Intensiva. 2011;35(8):478-83.

14. Bokslag A, Teunissen PW, Franssen C, van Kesteren F, Kamp O, Ganzevoort W, et al. Effect of early-onset preeclampsia on cardiovascular risk in the fifth decade of life. Am J Obstet Gynecol. 2017;216(5):523.e1523.e7.

15. Opitasari C, Andayasari L. Parity, education level and risk for (pre-) eclampsia in selected hospitals in Jakarta. Heal Sci $J$ Indones. 2014;5(1):35-9.

16. Bartsch E, Medcalf KE, Park AL, Ray JG, AlRubaie ZTA, Askie LM, et al. Clinical risk factors for pre-eclampsia determined in early pregnancy: Systematic review and metaanalysis of large cohort studies. $\mathrm{Br}$ Med J. $2016 ; 353$.

17. Wilson RL, Grieger JA, Bianco-Miotto T, Roberts CT. Association between maternal zinc status, dietary zinc intake and pregnancy complications: a systematic review. J Nutrient. 2016;8(641): 1 .

18. Fukada T, Kambe T. Welcome to the world of zinc signaling. Int. J. Mol. Sci. 2018;19(785):1.

19. Akhtar S, Begum S, Ferdousi S. Calcium and zinc deficiency in pre-eclamptic women. J Bangladesh Soc Physiol. 2011;6(2): 98.

20. Farzin L, Sajadi F. Comparison of serum trace element levels in patients with or without preeclampsia. J Res Med Sci. 2012;17(10):938-41.

21. Sarwar S, Ahmed S, Ullah MS, Kabir H, Rahman GK, Hasnat A, et al. Comparative study of serum zinc, copper, manganese, and iron in preeclamptic pregnant women. Biol Trace Elem Res J. 2013. 154:14-20.

22. Kambe T, Tsuji T, Hashimoto A, Itsumura N. The physiological, biochemical, and molecular roles of zinc transporters in zinc homeostasis and metabolism. Physiol Rev. 2015. 95:74950.

23. Olechnowicz J, Tinkov A, Skalny A, Suliburska J. Zinc status is associated with inflammation, oxidative stress, lipid, and glucose metabolism. J Physiol Sci. 2018;68:19.

24. Bettger WJ, O’Dell BL. A critical physiological role of zinc in the structure and function of biomembranes. Life Sci. 1981;28(13):1425-38.

25. MacDonald RS. The role of zinc in growth and cell proliferation. American society for nutritional Sciences. 2000:1500S-6S.

26. King JC, Determinants of maternal zinc status during pregnancy. Am $J$ Clin Nutr. 2000;71:1334S-43S.

27. Negi R, Pande D, Karki K, Kumar A, Khanna RS, Khanna HD. Trace elements and antioxidant enzymes associated with oxidative stress in the pre-eclamptic/eclamptic mothers during fetal circulation. European Society for 
Clinical Nutrition and Metabolism. Clinical Nutrition. 2012;31: 946-50.

28. National Center for Biotechnology Information [Internet]. PubChem Compound Summary for CID 62640, Zinc sulfate heptahydrate [cited 2021 January 20]. Available from: https://pubchem.ncbi.nlm.nih.gov/compoun d/Zinc-sulfate-heptahydrate.

29. Thomas JM, Shenoy RP, Bhat PV, Rao P. Pathophysiology of preeclampsia and possible role of zinc in its genesis. Current women's health reviews. $2014 ; 10(1): 38-41$ 
